\title{
Proteins Regulating Salivary and Lacrimal Flow in Xerostomia and Dry Eye Syndrome
}

\author{
Hina Nasim ${ }^{1}$ \\ Sarah Ghafoor ${ }^{2}$
}

\author{
BDS \\ BDS, BSc, PhD
}

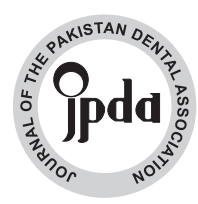

Oral and ocular homeostasis is dependent upon saliva, lacrimal fluid and their protein components. The function of major protein families regulating salivary and lacrimal fluid secretion is well established. The aim of this review is to summarize the role of different proteins that regulate salivary and lacrimal fluid secretion and to discuss mysregulations in diseased conditions especially xerostomia and dry eye syndrome. This review paper provides a detailed description of the abnormal localization and function of proteins, which could be responsible for loss of saliva and lacrimal fluid secretion in xerostomia and dry eye syndrome patients.

KEY WORDS: Proteins, Salivary flow, Lacrimal flow, Xerostomia, Dry eye syndrome.

HOW TO CITE: Nasim H, Ghafoor S. Proteins regulating salivary and lacrimal flow in xerostomia and dry eye syndrome. J Pak Dent Assoc 2019;28(2):92-97.

DOI: https://doi.org/10.25301/JPDA.282.92

Received: 18 October 2018, Accepted: 08 March 2019

\section{INTRODUCTION}

$O$ aliva is a complex fluid, secreted by salivary glands, plays an important role in health and maintenance of oral cavity through its vast array of functions including, lubrication, protection, buffering action, antimicrobial function, facilitates swallowing and taste, helps in digestion and tissue repair. ${ }^{1}$ Saliva has important diagnostic implications as it contains various biomarkers that can be helpful in detection and monitoring of various oral and systemic diseases. ${ }^{2}$

The lacrimal fluid, secreted by lacrimal glands, is essential for the maintenance of healthy eyes. It performs important functions such as protection of the eye by producing IgA and various antibacterial and fungicidal substances and molecules, the aqueous component keeps the ocular surface moist and helps in maintaining normal visual acuity. It is also important for the normal growth and maintenance of ocular tissue by producing various growth factors, for example, Epidermal growth factor, Fibroblast growth factor, Transforming growth factor-beta. ${ }^{3}$

Proper secretion of saliva and lacrimal fluid is dependent upon different proteins for example aquaporins, tight junction proteins and ion channel proteins. Defective structure and function of these proteins leads to mys-regularities in saliva and lacrimal fluid secretion, resulting in xerostomia and dry eye syndrome.

1. M.Phil Trainee, Department of Oral Biology, University of Health Sciences, Lahore

2. Assistant Professor, Department of Oral Biology, University of Health Sciences, Lahore.

Corresponding author: “Dr. Sarah Ghafoor” < sarahghafoor@uhs.edu.pk >

\section{Xerostomia in Common Clinical Conditions}

Salivary gland hypofunction leads to a clinical condition known as xerostomia. Xerostomia is defined as a subjective complaint of dry mouth due to insufficient secretion of saliva. ${ }^{4}$ The absence of saliva in the oral cavity can cause difficulty in swallowing, tasting and chewing, oesophagal dysfunction (chronic esophagitis), nutritional compromises, loss of oral buffering capacity, increased susceptibility to dental caries, inability to wear dental prostheses, increased susceptibility to mucosal injury, increased incidence of glossitis, candidiasis, halitosis, angular cheilitis, bacterial sialadenitis and Burning Mouth Syndrome. ${ }^{5}$

The local and systemic causes of xerostomia are given in table 1.

Xerostomia and hyposalivation have been reported as common oral manifestations of diabetes mellitus (DM). Xerostomia in DM patients can be due to a number of reasons, such as damage to the salivary gland parenchyma, alteration in the microcirculation of gland, dehydration and disturbed glycemic control, but the exact cause is still unknown. ${ }^{6}$ The salivary glands of head and neck are highly sensitive to radiation, and radiotherapy can cause temporary or permanent damage to the glands. Xerostomia is the most common presentation of glandular dysfunction in the head and neck region.$^{7}$ Sjogren's syndrome is an autoimmune disease of salivary and lacrimal glands, resulting in dry mouth and dry eyes. ${ }^{8}$ Xerostomia is common in the geriatric population. The main causes for xerostomia are attributed to different medications, long-term systemic diseases and head and neck radiotherapy. ${ }^{9}$ Ectodermal dysplasia is a 
Table 1: Causes of Xerostomia

\begin{tabular}{|c|c|c|}
\hline Causes & Examples & References \\
\hline 1. Medications & $\begin{array}{l}\text { Antihypertensive drugs (calcium } \\
\text { channel blockers, diuretics, beta } \\
\text { blockers) } \\
\text { Analgesics } \\
\text { Muscle relaxants } \\
\text { Anti-Parkinson drugs } \\
\text { Anti-emetics } \\
\text { Anxiolytics }\end{array}$ & Wolff et al.,2017 \\
\hline 2. Systemic Disorders & $\begin{array}{l}\text { Diabetes mellitus } \\
\text { Granulamatous diseases(tuberculosis, } \\
\text { sarcoidosis) } \\
\text { End-stage renal disease }\end{array}$ & $\begin{array}{l}\text { López-Pintor et al., } 2016 \\
\text { Babazade et al., } 2012 \\
\text { Postorino et al., } 2003\end{array}$ \\
\hline $\begin{array}{l}\text { 3. Autoimmune } \\
\text { Disorders }\end{array}$ & $\begin{array}{l}\text { Sjogren's syndrome } \\
\text { Mikulicz syndrome } \\
\text { Rheumatoid arthritis } \\
\text { Autoimmune thyroid disease } \\
\text { Systemic lupus erythmatosis }\end{array}$ & $\begin{array}{l}\text { Brito-Zerón et al., } 2016 \\
\text { Rao et al., } 2017 \\
\text { Zalewska et al., } 2013 \\
\text { Hammoudeh et al., } 2018\end{array}$ \\
\hline 4. Genetic Disorders & $\begin{array}{l}\text { Ectodermal dysplasia } \\
\text { LADD syndrome } \\
\text { ALSG syndrome } \\
\text { Cystic fibrosis } \\
\text { Down syndrome }\end{array}$ & $\begin{array}{l}\text { Lexner et al., } 2007 \\
\text { Pathivada et al.,2016 } \\
\text { Brandon et al., } 2009 \\
\text { Noël et al., 2008 } \\
\text { Chaushu et al., } 2002\end{array}$ \\
\hline 5. Others & $\begin{array}{l}\text { Head and neck radiotherapy } \\
\text { Dehydration } \\
\text { Old age } \\
\text { Bacterial and viral infections }\end{array}$ & $\begin{array}{l}\text { Berk et al., } 2005 \\
\text { Postorino et al.,2003 } \\
\text { Ouanounou et al., } 2016 \\
\text { Nokta et al., } 2008\end{array}$ \\
\hline
\end{tabular}

heterogeneous group of inherited disorders, which affects the development of tissues, derive from embryonic ectoderm. Decreased salivary flow has been reported in affected males and females with Ectodermal dysplasia due to defects in salivary glands development. ${ }^{10}$

\section{Dry eyes in Common Clinical Conditions}

Dry eye syndrome (DES) or keratoconjunctivitis sicca is a multifactorial disease, it is a common sequel of inadequate lacrimal fluid production, resulting in blurred vision, foreign body sensation, stinging sensation, photophobia or pain. ${ }^{11}$ There are many causes of keratoconjunctivitis sicca (Table 2).

Table 2: Causes of Keratoconjunctivitis Sicca (Dry eye syndrome)

\begin{tabular}{|c|l|l|}
\hline \multicolumn{1}{|c|}{ Causes } & \multicolumn{1}{|c|}{ Examples } & \multicolumn{1}{c|}{ References } \\
\hline 1. Inflammatory/ & $\begin{array}{l}\text { Sjogren's syndrome } \\
\text { Diabetes } \\
\text { Thyroid disease } \\
\text { Graft versus host disease } \\
\text { Sarcoidosis }\end{array}$ & $\begin{array}{l}\text { Brito-Zerón et al., 2016 } \\
\text { Zhang et al., 2016 } \\
\text { Kan et al.,2014 } \\
\text { Pasadhika et al., 2015 }\end{array}$ \\
\hline 3. Infections & $\begin{array}{l}\text { HIV } \\
\text { Hepatitis- C } \\
\text { CMV }\end{array}$ & $\begin{array}{l}\text { LADD syndrome et al., 2013 } \\
\text { ALSG syndrome } \\
\text { Cystic fibrosis }\end{array}$ \\
\hline 4. Genetic Dsorders & $\begin{array}{l}\text { Aging } \\
\text { Radiation therapy } \\
\text { Dehydration }\end{array}$ & $\begin{array}{l}\text { Pathivada et al., 2016 } \\
\text { Brandon et al., 2009 } \\
\text { Mrugacz et al., 2004 }\end{array}$ \\
\hline 5. Others & $\begin{array}{l}\text { De Paiva et al., 2017 } \\
\text { Turaka et al., 2016 }\end{array}$ \\
\hline \multicolumn{2}{|l}{} \\
\hline
\end{tabular}

Defective function of the lacrimal gland can occur due to various causes, including ageing, inflammation and infection and results in insufficient tear production that leads to various ocular complications. ${ }^{12}$

Dry eyes are also a distinctive feature of Sjogren's syndrome. It is characterized by chronic inflammation of salivary and lacrimal glands resulting in dry mouth and dry eyes. ${ }^{13}$ Dry eye syndrome is one of the common complications of diabetes mellitus. ${ }^{14}$ Hyperglycemia has an adverse effect on the lacrimal functional unit, leading to decrease tear production, or excessive tear loss, resulting in dry eye syndrome. ${ }^{15}$ Dry eye syndrome is common in elderly patients; the exact cause is still unknown. However, it is suggested that DES is related to biochemical, molecular and immune system disturbances. ${ }^{16}$ Dry eyes are an unfortunate side effect of radiotherapy. Radiotheraphy causes damage to the cells that leads to necrosis and apoptosis, resulting in the release of inflammatory mediators that are responsible for dry eye syndrome. ${ }^{17}$

\section{Proteins Regulating Salivary and Lacrimal Flow Proteins Involved in Salivary Secretion}

The major component of saliva is water which is approximately $99 \%$, and remaining $1 \%$ consist of electrolytes and salivary proteins. ${ }^{18}$ Major proteins families that are involved in salivary secretion are mentioned in table 3.

Table 3: Proteins Involved in Saliva Secretion

\begin{tabular}{|l|l|l|}
\hline \multicolumn{1}{|c|}{$\begin{array}{l}\text { Major Protein } \\
\text { Families }\end{array}$} & \multicolumn{1}{|c|}{ Examples } & References \\
\hline 1. Aquaporins & $\begin{array}{l}\text { Aquaporin-1 } \\
\text { Aquaporin-3 } \\
\text { Aquaporin-5 } \\
\text { Aquaporin-6 } \\
\text { Aquaporin-7 }\end{array}$ & Delporte et al., 2016 \\
\hline 2. Tight Junction & $\begin{array}{l}\text { Claudin } \\
\text { Occludin } \\
\text { Junctional adhesion molecule }\end{array}$ & Baker et al., 2016 \\
\hline 3. Linker Protein & $\begin{array}{l}\text { Ezrin } \\
\text { Radixin } \\
\text { Moesin }\end{array}$ & Pérez et al., 2010 \\
\hline 4. Ion Channel \\
$\begin{array}{l}\text { Proteins/ } \\
\text { Receptors }\end{array}$ & $\begin{array}{l}\text { Chloride channels (CFTR) } \\
\text { Calcium activated potassium } \\
\text { channels } \\
\text { TRPC } \\
\text { IP3R }\end{array}$ & Roussa et al., 2007 \\
\hline
\end{tabular}

\section{Aquaporins:}

Aquaporins (AQPs) is a family of transmembrane proteins, which serve an important role in transfer of water and some other solutes across the cell membranes. Until now, 13 types of AQP's have been identified (AQP 0- AQP 12)..$^{19}$

Aquaporin-1 protein expression has been found on the capillary epithelium and myoepithelial cells of salivary gland, aquaporin-3 localize to basolateral membranes of acinar cells and aquaporin- 5 has been found to be localized 
on canalicular and luminal membranes of acinar cells. ${ }^{20}$

The salivary secretion has been reported to be increased by upregulating the expression of aquaporin- 1 in xerostomia patients. ${ }^{21}$ Decreased expression of aquaporin-1 on myoepithlial cells of primary Sjogren's syndrome patients has been reported. ${ }^{22}$

In humans, AQP-5 mRNA has been detected in submandibular gland by RT-PCR. Functionally, it is believed that AQP-5 is the aquaporin which seems to play an important role in saliva secretion. It helps in primary saliva production. ${ }^{23}$ Abnormal localization of AQP-5 has been reported in Sjogren's syndrome ( $\mathrm{SS}$ ) patients as compared to non-Sjogren's syndrome patients with xerostomia. AQP-5 was found to be present at both apical and basolateral membrane in SS patients as compared to non- SS patients in which the AQP-5 was restricted to the apical membrane of acinar cells. ${ }^{24}$ The defect in the AQP-5 trafficking in parotid glands has been reported in streptozocin-induced diabetic rats. ${ }^{25}$

\section{Tight Junction Proteins}

Tight junctions also known as occluding junctions are a multiprotein junctional complex, whose primary function is to prevent leakage of transported solute and water, thus they seal the paracellular pathway. The main tight junction proteins are occludin, claudin and junctional adhesion molecule. ${ }^{26}$ Occludin has been found on the ductal and acinar cells of human major salivary glands and endothelial cells. ${ }^{27}$ The occludin level has been reported to be downregulated in patients with Sjogren's syndrome. ${ }^{28}$ Claudin is the most important protein of tight junctions; it controls paracellular as well as the intercellular flow of molecules. ${ }^{29}$ Claudin ${ }^{1}$ has been found on striated and intercalated duct epithelium of human salivary glands. Caludin -2 has been detected on acinar cells of human salivary glands. ${ }^{30}$ Claudin3 has been detected on mucus and serous acinar cells of human salivary glands and Claudin-4 has been detected both on ductal and acinar cells of human salivary glands. ${ }^{31}$ Claudin play important role in saliva secretion by maintianing cell polarity and tansepithalial gradient necessary for unidirectional flow of saliva. ${ }^{32}$

\section{Linker Protein (Ezrin)}

Ezrin is a cytoplasmic peripheral membrane protein that serves as a bridge between the plasma membrane and the actin cytoskeleton, it plays an important role in cell adhesion, organization and migration. Ezrin was reported to be colocalized with actin at apical membrane and plays an important role in microvilli organization. ${ }^{33}$ Abnormal localization of ezrin has been reported in acinar cells of Sjogren's syndrome patients. ${ }^{34}$

\section{Ion Channel Proteins}

Ion channel proteins are found in cell membranes, through which ions and electrolytes can move in and out of the cell ${ }^{35}$ The acinar cells of salivary glands express different types of ion channel proteins, that are present mostly on apical or basolateral membranes, to facilitate fluid secretion ${ }^{36}$ Cystic fibrosis transmembrane regulator (CFTR) is a protein and chloride channel that controls the fluid and electrolyte transport in epithelial cells. In human salivary gland, CFTR has been found on the luminal surfaces of striated ducts. ${ }^{37}$ Mutations or any abnormality in CFTR has been reported to be associated with altered salivary function in cystic fibrosis patients. ${ }^{38}$

\section{Proteins Involved in Lacrimal Fluid Secretion}

The lacrimal fluid comprises mainly of water, electrolytes, proteins \& metabolites in smaller quantities. Major proteins that are involved in lacrimal fluid secretion are given in table 4.

Table 4: Proteins Involve in Lacrimal Fluid Secretion

\begin{tabular}{|l|l|l|}
\hline Major Protein Families & Examples & Reference \\
\hline Aquaporins & AQP-1 & Verkman et al., 2008 \\
& AQP-3 & \\
& AQP-4 & \\
AQP-5 & Cx 32 & Walcott., 2002 \\
\hline Gap Junction Proteins & Serotinin & Imada et al., 2017 \\
\hline Hormones (serotinin) & CFTR & Berczeli et al., 2018 \\
\hline Ion Channel Proteins & $\begin{array}{l}\text { PRR4 } \\
\text { S100A8 }\end{array}$ & Perumal et al., 2016 \\
\hline $\begin{array}{l}\text { Extracellular and Cytoplasmic } \\
\text { Proteins }\end{array}$ & $\begin{array}{l}\text { DMBT1 } \\
\text { PROL1 }\end{array}$ \\
\hline
\end{tabular}

\section{Auqaporins}

In eyes, the aqueous component of tear film/lacrimal fluid is regulated by aquaporins. ${ }^{39}$ The main aquaporins that have been found on the acinar and ductal cells of lacrimal glands are; AQP-1, AQP-3, AQP-4and AQP-5. ${ }^{40}$ The expression of AQP-5 has been found on the acinar and ductal cells of rat and mice. ${ }^{41}$ Aquaporin- 5 expression have also been found on the apical surface of acinar cells in human lacrimal glands. A defect in aquaporin- 5 trafficking and lacrimal fluid secretion have also been reported in Sjogren's syndrome patients. ${ }^{42}$ The expression of aquaporin-4 and -5 was altered in pregnant rabbits with induced autoimmune dacryoadenitis. ${ }^{43}$

\section{Gap Junction Proteins}

Gap junctions are organized clusters of protein channels present in cell membranes that permit transfer of small molecules and ions between neighbouring cells. These 
channels are made up of connexon proteins . The acinar cells of lacrimal glands are attached to each other by gap junctions. The main gap junction proteins present in lacrimal glands are Cx 32 and Cx $26 .{ }^{44}$ Decreased lacrimal flow has been reported in $\mathrm{Cx} 32$ null mice, which suggests that gap junctions play an important role in lacrimal fluid secretion. ${ }^{45}$

\section{Serotonin Protein}

Serotonin derived from amino acid tryptan, performs a multiple array of functions. In brain it functions as a neurotransmitter, while in peripheral organs it acts as a hormone or a signalling molecule. ${ }^{46}$ Recently, it has been reported that decrease level of serotinin in blood is related to lacrimal gland atrophy and autophagy leading to loss of tear production in a mice model..$^{47}$

\section{Ion Channel Proteins}

CFTR is a chloride channel that plays an important role in fluid transport across epithelial cells. ${ }^{48}$ It has been reported that CFTR is present on acinar and ductal cells of rat and rabbit model. Recently, decrease in the production of lacrimal fluid has been reported in knockout mice. ${ }^{49}$

\section{Extracellular and Cytoplasmic Proteins}

In addition to above mentioned proteins, there are various extracellular and cytoplasmic proteins that are involved in the formation of tear film such as PRR4, S100A8, DMBT1 and PROL1. It has been reported that some of these proteins were differntially expressed in dry eye syndrome patients as compared to controls and the pathology of DES can be associated with decrease expression of these proteins. ${ }^{13}$

\section{CONCLUSION}

Xerostomia and dry eye syndrome occurring due to defects in salivary and lacrimal fluid secretion can result in a multifacet degradation of patients' quality of life. Xerostomia is caused by disturbances in regulation of protiens such as aquaporins ( APQ-1 \& -5), tight junction proteins (occludin, claudin), linker protein (ezrin) and ion channel proteins (CFTR). Similiarly, dry eye syndrome is caused by defective funstioning of aquaporins ( APQ-4 \& -5), gap junction proteins ( $\mathrm{Cx} 32$ and $\mathrm{Cx} 26$ ), ion channel proteins and extracellular and cytoplasmic proteins.

Further research can explore possibilities of these molecules as relevant biomarker for abnormal conditions associated with salivary and lacrimal fluid flow.

\section{ACKNOWLEGMENTS}

The authors would like to thank the Higher Education
Commission of Pakistan (HEC) for providing e-Library access through which published data for this manuscript was retrived.

\section{CONFLICT OF INTREST}

The authors declare no conflict of intrest

\section{Funding}

None to declare

\section{REFERENCES}

1. Dawes C, Pedersen AM, Villa A, Ekstrom J, Proctor GB, Vissink A, et al. The functions of human saliva: A review sponsored by the World Workshop on Oral Medicine VI. Arch Oral Biol. 2015;60:86374.

https://doi.org/10.1016/j.archoralbio.2015.03.004

2. Khurshid Z, Haq JA, Khan BRS, Altaf M, Najeeb S. Human saliva and its role in oral \& systemic health. J Pak Dent Assoc. 2016;25:171.

3. Conrady CD, Joos ZP, Patel BC. The lacrimal gland and its role in dry eye. J Opthamol.2016;7542929

https://doi.org/10.1155/2016/7542929

4. Villa A, Connell CL, Abati S. Diagnosis and management of xerostomia and hyposalivation. Ther Clin Risk Manag. 2015;11:45.

5. Friedman PK, Isfeld D. Xerostomia: the "invisible" oral health condition. J Mass Dent Soc. 2008;57:42-4.

6. López-Pintor RM, Casa-as E, González-Serrano J, Serrano J, Ramírez L, de Arriba L, et al. Xerostomia, Hyposalivation, and Salivary Flow in Diabetes Patients. J Diabetes Res 2016;2016:4372852. https://doi.org/10.1155/2016/4372852

7. Berk LB, Shivnani AT, Small W, Jr. Pathophysiology and management of radiation-induced xerostomia. J Support Oncol. 2005;3:191-200.

8. Alam J, Choi YS, Koh JH, Kwok S-K, Park S-H, Song YW, et al. Detection of Autoantibodies against Aquaporin-1 in the Sera of Patients with Primary Sjögren's Syndrome. Immune Netw. 2017;17:103-9. https://doi.org/10.4110/in.2017.17.2.103

9. Ouanounou A. Xerostomia in the Geriatric Patient: Causes, Oral Manifestations, and Treatment. Compend Contin Educ Den. 2016;37:306-311;quiz312.

10. Lexner MO, Bardow A, Hertz JM, Almer L, Nauntofte B, Kreiborg $\mathrm{S}$. Whole saliva in X-linked hypohidrotic ectodermal dysplasia. Int J Paediatr Dent. 2007; 17:155-62.

https://doi.org/10.1111/j.1365-263X.2006.00812.x

11. Javadi M-A, Feizi S. Dry Eye Syndrome. J Ophthalmic Vis Res. 2011;6:192-98

12. Conrady CD, Joos ZP, Patel BC. Review: The Lacrimal Gland and Its Role in Dry Eye. J Ophthalmol. 2016;2016,:7542929. 
13. Perumal N, Funke S, Pfeiffer N, Grus FH. Proteomics analysis of human tears from aqueous-deficient and evaporative dry eye patients. Scientific reports. 2016;6:29629.

https://doi.org/10.1038/srep29629

14. Zhang X, Zhao L, Deng S, Sun X, Wang N. Dry Eye Syndrome in Patients with Diabetes Mellitus: Prevalence, Etiology, and Clinical Characteristics. J Ophthalmol. 2016;2016:8201053.

https://doi.org/10.1155/2016/8201053

15. Goebbels M. Tear secretion and tear film function in insulin dependent diabetics. Br J Ophthalmol. 2000;84:19-21. https://doi.org/10.1136/bjo.84.1.19

16. de Paiva CS. Effects of Aging in Dry Eye. Int ophthalmol clin.2017;57:47-64.

https://doi.org/10.1097/IIO.0000000000000170

17. Turaka K, Turaka A. Diagnosis and Treatment of Radiation Therapy induced Ocular Surface Disorders. OMICS J Radiol. 2016;5:e138. https://doi.org/10.4172/2167-7964.1000e138

18. De Almeida PDV, Gregio A, Machado M, De Lima A, Azevedo LR. Saliva composition and functions: a comprehensive review. J Contemp Dent Pract. 2008;9:72-80.

19. Delporte C. Aquaporins in salivary glands and pancreas. Biochim Biophys Acta.2014;1840:1524-32.

https://doi.org/10.1016/j.bbagen.2013.08.007

20. Gresz V, Kwon TH, Hurley PT, Varga G, Zelles T, Nielsen S, et al. Identification and localization of aquaporin water channels in human salivary glands. Am J Physiol Gastrointest Liver Physiol.2001;281:G247-G54.

https://doi.org/10.1152/ajpgi.2001.281.1.G247

21. Wang Z, Pradhan-Bhatt S, Farach-Carson MC, Passineau MJ. Artificial Induction of Native Aquaporin-1 Expression in Human Salivary Cells. J Dent Res. 2017;96:444-49.

https://doi.org/10.1177/0022034516685045

22. Beroukas D, Hiscock J, J Gannon B, Jonsson R, P Gordon T, A Waterman S. Selective down-regulation of aquaporin-1 in salivary glands in primary sjögren's syndrome. Lab Invest.2002;82:1547-52.

23. Wang W, Hart PS, Piesco NP, Lu X, Gorry MC, Hart TC. Aquaporin expression in developing human teeth and selected orofacial tissues. Calcif Tissue Int. 2003;72:222-27.

https://doi.org/10.1007/s00223-002-1014-9

24. Steinfeld S, Cogan E, King LS, Agre P, Kiss R, Delporte C. Abnormal distribution of aquaporin-5 water channel protein in salivary glands from Sjögren's syndrome patients. Lab Invest. 2001;81:14348 .

https://doi.org/10.1038/labinvest.3780221

25. Ishikawa Y, Inoue N, Zhenfang Y, Nakae Y. Molecular mechanisms and drug development in aquaporin water channel diseases: the translocation of aquaporin-5 from lipid rafts to the apical plasma membranes of parotid glands of normal rats and the impairment of it in diabetic or aged rats. J Pharmacol Sci. 2004;96:271-75.

https://doi.org/10.1254/jphs.FMJ04004X6

26. Tsukita S, Yamazaki Y, Katsuno T, Tamura A, Tsukita S. Tight junction-based epithelial microenvironment and cell proliferation. Oncogene. 2008;27:6930-38.

https://doi.org/10.1038/onc.2008.344

27. Maria OM, Kim J-WM, Gerstenhaber JA, Baum BJ, Tran SD. Distribution of Tight Junction Proteins in Adult Human Salivary Glands. J Histochem Cytochem. 2008;56:1093-98.

https://doi.org/10.1369/jhc.2008.951780

28. Ewert P, Aguilera S, Alliende C, Kwon YJ, Albornoz A, Molina $\mathrm{C}$, et al. Disruption of tight junction structure in salivary glands from Sjogren's syndrome patients is linked to proinflammatory cytokine exposure. Arthritis Rheum. 2010;62:1280-89.

https://doi.org/10.1002/art.27362

29. Günzel D, Yu ASL. Claudins and the Modulation of Tight Junction Permeability. Physiol Rev. 2013;93:525-69. https://doi.org/10.1152/physrev.00019.2012

30. Maria OM, Kim J-WM, Gerstenhaber JA, Baum BJ, Tran SD. Distribution of Tight Junction Proteins in Adult Human Salivary Glands. J Histochem Cytochem. 2008;56:1093-98.

https://doi.org/10.1369/jhc.2008.951780

31. Lourenço SV, Coutinho-Camillo CM, Buim ME, Uyekita SH, Soares FA. Human salivary gland branching morphogenesis: morphological localization of claudins and its parallel relation with developmental stages revealed by expression of cytoskeleton and secretion markers. Histochem Cell Biol. 2007;128:361-69. https://doi.org/10.1007/s00418-007-0322-6

32. Baker OJ, Camden JM, Redman RS, Jones JE, Seye CI, Erb L, et al. Proinflammatory cytokines tumor necrosis factor-a and interferon? alter tight junction structure and function in the rat parotid gland Par-C10 cell line. Am J Physiol Cell Physiol. 2008;295:C1191-C201. https://doi.org/10.1152/ajpcell.00144.2008

33. Berryman M, Franck Z, Bretscher A. Ezrin is concentrated in the apical microvilli of a wide variety of epithelial cells whereas moesin is found primarily in endothelial cells. J Cell Sci. 1993;105 (Pt 4):102543.

34. Pérez P, Aguilera S, Olea N, Alliende C, Molina C, Brito M, et al. Aberrant localization of ezrin correlates with salivary acini disorganization in Sjögren's Syndrome. Rheumatology. 2010;49:91523.

https://doi.org/10.1093/rheumatology/keq033

35. Gadsby DC. Ion channels versus ion pumps: the principal difference, in principle. Nat Rev Mol Cell Biol. 2009;10:344-52. https://doi.org/10.1038/nrm2668

36. Catalán MA, Pe-a-Munzenmayer G, Melvin JE. Ca(2+)-dependent $\mathrm{K}(+)$ Channels in Exocrine Salivary Glands. Cell calcium. 2014;55: 362-68.

https://doi.org/10.1016/j.ceca.2014.01.005 
37. Webster P, Vanacore L, Nairn AC, Marino CR. Subcellular localization of CFTR to endosomes in a ductal epithelium. Am J Physiol Cell Physiol. 1994;267:C340-C8.

https://doi.org/10.1152/ajpcell.1994.267.2.C340

38. Livnat G, Bentur L, Kuzmisnsky E, Nagler RM. Salivary profile and oxidative stress in children and adolescents with cystic fibrosis. J Oral Pathol Med. 2010;39:16-21.

https://doi.org/10.1111/j.1600-0714.2009.00813.x

39. King LS, Yasui M. Aquaporins and disease: lessons from mice to humans. Trends Endocrinol Metab. 2002;13:355-60. https://doi.org/10.1016/S1043-2760(02)00665-3

40. Verkman AS, Ruiz-Ederra J, Levin MH. Functions of Aquaporins in the Eye. Prog Retin Eye Res. 2008;27:420-33.

https://doi.org/10.1016/j.preteyeres.2008.04.001

41. Hamann S, Zeuthen T, La Cour M, Nagelhus EA, Ottersen OP, Agre $\mathrm{P}$, et al. Aquaporins in complex tissues: distribution of aquaporins 1-5 in human and rat eye. Am J Physiol Cell Physiol. 1998;274 (5 Pt 1):C1332-45.

https://doi.org/10.1152/ajpcell.1998.274.5.C1332

42. Tsubota K, Hirai S, King LS, Agre P, Ishida N. Defective cellular trafficking of lacrimal gland aquaporin-5 in Sjögren's syndrome. The Lancet. 2001;357(9257):688-89.

https://doi.org/10.1016/S0140-6736(00)04140-4

43. Ding C, Nandoskar P, Lu M, Thomas P, Trousdale MD, Wang Y. Changes of aquaporins in the lacrimal glands of a rabbit model of
Sjogren's syndrome. Curr Eye Res. 2011;36:571-78.

https://doi.org/10.3109/02713683.2011.574330

44. Hareyama M, Fujimoto K, Honda Y, Ogawa K, Ide C. Dynamics of gap junction protein connexins in rat exorbital lacrimal glands during postnatal stages. Acta histochemica et cytochemica. 1994;27:535-43. https://doi.org/10.1267/ahc.27.535

45. Walcott B, Moore LC, Birzgalis A, Claros N, Valiunas V, Ott T, et al. Role of gap junctions in fluid secretion of lacrimal glands. Am J Physiol Cell Physiol. 2002;282:C501-C7.

https://doi.org/10.1152/ajpcell.00004.2001

46. El-Merahbi R, Loffler M, Mayer A, Sumara G. The roles of peripheral serotonin in metabolic homeostasis. FEBS Lett. 2015;589:1728-34. https://doi.org/10.1016/j.febslet.2015.05.054

47. Imada T, Nakamura S, Hisamura R, Izuta Y, Jin K, Ito M, et al. Serotonin hormonally regulates lacrimal gland secretory function via the serotonin type 3a receptor. Sci Rep. 2017;7:6965. https://doi.org/10.1038/s41598-017-06022-4

48. Dartt DA. Neural regulation of lacrimal gland secretory processes: relevance in dry eye diseases. Prog Retin Eye Res. 2009;28:155-77. https://doi.org/10.1016/j.preteyeres.2009.04.003

49. Berczeli O, Vizvári E, Katona M, Török D, Szalay L, Rárosi F, et al. Novel Insight Into the Role of CFTR in Lacrimal Gland Duct Function in Mice. Invest Ophthalmol Vis Sci. 2018;59:54-62. https://doi.org/10.1167/iovs.17-22533 